\title{
Organizational Climate and Work Style: The Missing Links for Sustainability of Leadership and Satisfied Employees
}

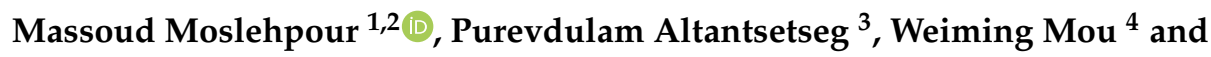 \\ Wing-Keung Wong $5,6,7, *$ (D)
}

1 Department of Business Administration, Asia University, Taichung 41354, Taiwan; writetodrm@gmail.com 2 Department of Business Administration, Saigon Institute of Technology, District 12, HCMC 70000, Vietnam 3 Law School, Mongolian National University, Ulaanbaatar 16060-0012, Mongolia; pvrevdulam@gmail.com

4 College of Economics and Management, Changzhou Institute of Technology, Changzhou 213022, China; muwm@czu.cn

5 Department of Finance, Fintech Center, and Big Data Research Center, Asia University, Taichung 41354, Taiwan

6 Department of Medical Research, China Medical University Hospital, Taichung 40402, Taiwan

7 Department of Economics and Finance, Hang Seng University of Hong Kong, Shatin, Hong Kong 999077, China

* Correspondence: wong@asia.edu.tw; Tel.: +886-4-2332-3456

Received: 18 October 2018; Accepted: 10 December 2018; Published: 27 December 2018

check for updates

\begin{abstract}
People try to find the role of government in today's modern society. Citizens of any country look forward to benefit from government services. Although the government implements laws and policies in all areas of society, people only know about it through government's services. We describe a good government's service of organization, department, unit, and division that has an appropriate human strategy. Purpose: Purpose of this study is to investigate which factors have been missing that connects and maintains the sustainability between the leadership style and employees' satisfaction in the government sector of Mongolia. More specifically, the purpose of the study is to investigate the missing link between leadership style and job satisfaction among Mongolian public sector employees. This study reiterates the mediating role of organizational climate (OC) and work style (WS) in a new proposed model. Methodology: The questionnaire is designed by a synthesis of existing constructs in current relevant literature. The research sample consisted of 143 officers who work in the primary and middle units of the territory and administration of Mongolia. Factor analysis, a reliability test, a collinearity test, and correlation analyses confirm the validity and reliability of the model. Multiple regression analysis, using Structural Equation Modeling (SEM), tests the hypotheses of the study. The sample of this study is chosen from the public organization. Mongolia is a developing country. This country needs good public leaders who can serve citizens. This study will be extended further. In addition, Mongolia really needs sufficient studies. Practical implications: This study has several important implications for studies related to organizational behavior and job satisfaction. Furthermore, the implications of these findings are beneficial to organizations aimed at improving policies and practices related to organizational behavior and human resource management. Regulators and supervisors of private or public organizations aiming to increase the level of their employees' job satisfaction will also benefit from the findings. Therefore, this study's new proposed model can be the basis of fundamental research to build a better human resource policy. Although the leadership style is an influential factor for job satisfaction, this study identifies the mediating missing links between the leadership style and employees' job satisfaction. Findings: The findings of this research indicate that the organizational climate and work style complement and fully mediate the relationship between leadership style and job satisfaction. An appropriate leadership style is most effective when it matches the organizational climate as well as employees'
\end{abstract}


work style. Furthermore, a suitable organizational climate will increase the level of job satisfaction. If the work style of employees is respected and taken into consideration, the leadership style can find its way into job satisfaction. Originality/value: This study is the first to understand the motivators of job satisfaction in the government sector of Mongolia. This study suggests valuable findings for executive officers who are junior and primary unit's officers of the register sector of government in Mongolia. The findings of this study help managers and executives in their effort develop and implement successful human resource strategies.

Keywords: job satisfaction (JS); work style (WS); leadership style (LS); organizational climate (OC); register office; Mongolia

JEL Classification: D23; J01; J24; J28; J45; J53; J81; M12

\section{Introduction}

In Mongolia, it is more likely for the job seekers to pursue employment in government sectors such as a register office than in private companies. Young graduates encouraged by their parents are urged to become a civil servant and to seek a position in the government. Although satisfaction with the organizations is one of the most crucial factors in the sustainability of private companies [1], it does not seem to be the same situation in public sector organizations. Often, a low level of job satisfaction is observed in public sector organizations. Buchanan [2] and Lachman [3] concluded that employees in the public sector are less satisfied with their work than private companies' employees do. Employees who work in primary units of government or in provinces are less satisfied with their leader/supervisors. Efficient leadership and management style can help increase employee satisfaction [4].

While the public sector organization has been receiving increasing attention in the last two decades, little research focuses specifically on the job satisfaction of the registration organization [5]. In this sector, there is still a lack of performance appraisal, employee job satisfaction, workload balance, and a healthy subordinate-supervisory relationship. The registration organization in Mongolia, especially the primary administrative units and provinces, is less technologically resourced largely due to a vertical organizational structure and underpaid employees. The organizational climate seems to depend also on the particular characteristics of the work environment [4,6-8]. Employees should realize the positive organizational importance and they should create it for success.

Job satisfaction literature has been studied in private sector organizations. Recent empirical studies have looked at service industries and service firms [9]. To our knowledge, there are almost no empirical studies exploring the employees' job satisfaction in the Mongolian public organization in the government register sector. Our study includes registrars, inspector, and administrative staff of the Mongolian register organization. In this sector, there are no contemporary studies of registrars' job satisfaction. None of the previous studies looked at the influence leadership style on job satisfaction through the organizational climate and work style. The current study is an attempt to address this gap in the literature. We hypothesized that the leadership style with the presence of the organizational climate and work style has no direct effect on job satisfaction. However, the leadership style through the organizational climate and work style will have an indirect effect on employees' job satisfaction. In this study, we aim to investigate how the leadership style through meditating factors, synchronously and asynchronously, influence job satisfaction of registration organization employees. The organizational climate and work style are synchronous mediators since they work in parallel to influence the relationship between leadership style and job satisfaction. The organizational climate and work style also mediate the relationship between leadership style and job satisfaction synchronously 
as they work in series. Figure 1 depicts visually the synchronous and asynchronous influences of the mediators.

\section{Literature Review and Hypotheses Development}

This section reviews motivator factors used in this paper including work style, leadership style, and organizational climate studies relevant to job satisfaction. In addition, the relationship among the variables leading to the development of the hypotheses is discussed.

\subsection{Leadership Style (LS)}

Leadership is one of the main factors for success [10] in any kind of group activities. The leadership style inspires people with a specific vision to work, helps clarify some concrete goals, and motivates and helps employees communicate well within their team. Wilkinson and Wagner [11] show that the leaders' significant support influences employees' attitude. According to Drucker [12], the style of leadership is an engine of effective organization and it is based on the interaction between leader and employees in the workplace. Furthermore, Edgar and Geare [13] argue that the workers-leader relationship is a key factor that influences workers' satisfaction in their workplace. In this regard, the leader represents his/her employees and lets employees assess their leader.

Alola, Avci, and Ozturen [14] study the effect of leadership style on job satisfaction in the Nigerian tourist industry. The results show that the leadership style affects hotel employees' job satisfaction. Transformational Leadership emphasizes an increasing work commitment, job satisfaction, and well-being of the employees $[15,16]$. Authentic Leadership depends on the organizational context and an individual's positive psychological attitude. This type of leadership determines self-awareness and self-regulated positive behaviors of both leaders and employees. Entrepreneurial leadership converges and directs the group members' performances toward the attainment of organizational objectives that involves identifying and implementing entrepreneurial opportunities [17]. The following sections discuss and define the variables of this study.

\subsection{Organizational Climate (OC)}

According to McGregor [18], the organizational climate is defined as how employees perceive organizations' internal functions like decision-making and rule-setting in the workplace. It can also be defined as a set of behaviors that describe an organization [19]. An organizational climate can be specific for each organization. It may make an organization different from other organizations and influence employees' work behavior in the organization. The organizational climate can also leave a perception in the employees' mind towards the management of their working unit [20]. It is related to employees' perceptions on their own and other colleagues' effectiveness in job and task implementation. In organizations that are public or private where employees' perception of their organizational climate is more egoistic and less ethical, employees are more prone to corruption [21].

Griffin [22] suggests that the climate generally refers to direct perceptions of the work environment. Organizations need a positive climate in their workplace to boost employee motivation and raise the opportunity that employees will implement adequate efforts doing their tasks. Therefore, a positive climate encourages employees' productivity and decreases turnover. Thus, it is vital for business success. Chang, Wu, and Liu [23] collected data from 34 human resources managers and 354 employees working in the Chinese manufacturing and service industries. Their results demonstrate that work style and workplace events influence employees' job satisfaction. A three-year study $(2007,2009,2010)$ of 5656, 6274, and 5841 public employees facilitated by the Ministry of Labor and Social Security of Spain indicates that the organizational climate is among the top five influential factors of job satisfaction among the employees [24].

According to Jung, Chow, and $\mathrm{Wu}$ [25] and Jung and Ali [26], the organizational climate is one of the most important characteristics of a great and comfortable workplace. Therefore, if a leader can create a great workplace, it will increase employees' productivity. Several studies [27-29] point out the 
positive impact of leadership style on the organizational climate. There is, however, a lack of research with the Mongolian population and specifically Mongolian government employees. Therefore, in this paper, we follow the previous study's suggestions to make the following hypothesis for LS and OC for Mongolian register office employees.

H1. LS has a positive association with OC.

\subsection{Work Style (WS)}

There are several definitions of work styles proposed by researchers. Mihut [30] suggests that the work style is the combination of professional, organizational, political, and moral qualities expressed in daily professional activities of individuals. Dawis and Lofquist [31] define work styles as an employee's originally conceived working attributes. These traits are generally established in childhood through experimentation, which crystallized in adulthood and declined due to the aging process. Subsequently, an individual might possess the appropriate skills and abilities to meet the demands of the job. However, if the work style is ineffectively communicated or perceived, the job environment satisfies neither the employer nor the employee. Work styles, thus, have an impact for job satisfaction [31,32]

Niculiţă [33] has observed the relationship between work style and organizational climate in the scope of Romanian employees. He found that there are several factors in an organizational climate that can influence some specific work style factors such as a positive interpersonal relationship, a positive motivation, an effective and efficient management in an organization, and organizational support. Therefore, the organization climate has a significant impact on work style. In this paper, we follow his suggestion to make the following hypothesis for OC and WS for Mongolian register office employees.

H2. OC has a positive association with WS.

\subsection{Job Satisfaction (JS)}

In organizational behavior studies, there are numerous definitions of job satisfaction. Locke [34] defines employee's satisfaction to be the positive emotional state stemming from the evaluation of a person's experience associated with the job. According to Spector [35], job satisfaction is the degree to which one likes his or her job. However, Brief's [36] job satisfaction represents an attitude towards the job. Mathieu and Zajac [37] and Hirschfeld, Field, and Bedeian [38] define the term to be the result of some factors that affect the quality of individuals' working life. On the other hand, Altuntas and Baykal [39] state that job satisfaction is of interest to employers. Job satisfaction continues to be studied since it is considered to be a desirable outcome of employment [39]. This study is based on previous findings and the notion introduced by Durst and DeSantis [40] that employee's satisfaction is important in public sector employees who are often perceived as unhappy workers. Their low morale may be associated with low productivity.

Job satisfaction is an important factor in an organization that the absence of it can lead to team's lethargy and a lack of enthusiasm so that it may reduce organizational commitment. If there is a lack in job satisfaction, it may cause some good employees to quit their jobs [41].

Many studies have observed the positive relationship between work style and job satisfaction. For example, Dawis and Lofquist [31] shows that work style positively influences job satisfaction. They found that, even though employees have the appropriate skills and abilities to meet the demands of their jobs and their work style is ineffectively expressed, their manager would not be fully satisfied with their performance. Thereby, it is necessary for employees to have a decent work style in order to make their manager/leader satisfied with their performance. Empirical studies by Arbuckle et al. [42], Chang et al. [43], Chuang et al. [44], Harley et al. [45], Harmon et al. [46], and Young et al. [47] show that a high-performance work system has been connected with higher employee satisfaction. Fan et al. [48] indicated that the high level of adoption would increase job satisfaction. Based on the information 
above, in this paper, we follow previous studies' suggestions to make the following hypothesis for OC and WS for the Mongolian register office employees.

H3. WS has a positive association with JS.

\subsection{Mediators between Leadership Style and Job Satisfaction}

The relationship between leadership style and job satisfaction is one of the most critical factors for success in an organization $[49,50]$. Several studies have looked at this relationship and established the significant influence of leadership style on job satisfaction [49,51-53]. Some studies went beyond and looked at the intermediary influence of the organizational climate [54]. Jung and Ali [26] look at the influence of organizational climate as the moderator between corporate social responsibility and job satisfaction.

Leadership style and the organizational climate have been reported to positively and significantly influence employee satisfaction [55]. Priyankara et al. [56] reported on employees of textile and apparel manufacturing factories in Sri Lanka. Their findings indicate that the organizational climate is the partial mediator between leader's support and employee behavior. Experimental evidence from the Alola, Avci, and Ozturen [14] study in Nigeria shows that work style mediates the relationship between leadership style and job satisfaction. In this paper, based on the previous findings, we made the following hypothesis for LS and JS with OC and WS as mediators for Mongolian register office employees.

H4. OC mediates the relationship between LS and JS.

H5. WS mediates the relationship between LS and JS.

H6. OC and WS are serial multiple mediators between LS and JS.

\subsection{Mediator between Leadership Style and Work Style}

Leaders have their own leadership style towards their employees while each employee also has their individual work style [33]. Work style is the accumulation of personalized work-related experiences. Different definitions of work style result in typologies with different theoretical or applied values. For example, Scherpereel and Bowers [57] have designed several workshops that aim to help create work teams based on heterogeneity and complementarity. In their approach, work style during teamwork consists of four different classifications: doers, expressive, amiable, and analytics works. These work styles together have strong correlation with leadership style. Work style in the organization depends on leadership style [33]. Leaders have their own leadership style to lead their employees. In addition, the style of work offered in different organizations may not be the same [58-60]. Sarros et al. [61] examined the relationship between leader's behavior (transactional and transformational styles) and aspects of an organization's structure (i.e., centralization, formalization dimensions). In this paper, we hypothesize that organizational culture is the mediator that has not been studied previously. The following hypothesis for LS and WS with OC as the mediator for Mongolian register employees.

H7. OC mediates the relationship between LS and WS.

\subsection{Mediator between Organizational Climate and Job Satisfaction}

Many studies have observed a positive relationship between the organizational climate and job satisfaction. For example, Chen and Spector [62], Brockner [63], and De Cremer [64] have shown that negative leader-employee interactions have a negative influence on the employees' satisfaction, which results in signs of stress and unwillingness to go to work. Tsai [65], Hashemi and Sadeqi [41], Ángel Calderón Molina et al. [66], and Ahmad et al. [67] predict that the organizational climate has a significant effect on job satisfaction. In this paper, we introduce work style as a 
mediator. The organizational climate is also related to employee corruption [21]. We mentioned that organizational climate influences work style. We also established that work style has a positive association with job satisfaction. Based on previous research findings, we make the following hypothesis for OC and JS with WS as the mediator for Mongolian register employees.

H8. WS mediates the relationship between OC and JS.

\section{Research Methodology}

\subsection{Sample Selection and Instrumentation}

This paper uses a convenient sampling technique in which we select the registration sector of Mongolian government units accessible via postal mail or email. Data is gathered from 143 employees who are working in primary and middle units of administration in the Mongolian registration offices. The survey questionnaires of this paper are fundamentally built by the features that are chosen based on the considerations of the research framework, definitions of the variables, and literature reviews. Most of the items of the instrument are based on questions used in previous research. Some questions are used in their original form while others are slightly modified to address the specific nature of this study. In the design of a questionnaire for our survey, a complex construct is used in order to enrich both the meaning and multi-dimensionality.

\subsection{Data Analysis Procedure}

Structured and unstructured observations are used in this study. After collecting some information relevant to the Mongolian government's structure and administration, sample data is collected from the registration organization's primary and middle units of the Mongolian government. Second, the interview method is used in this study before the sample is collected. The data is collected from leaders/supervisor of government employees of the register office of Mongolia. Questions are based on theoretical and previous empirical studies and the result of the observation and interviews. Method of analysis of the sample is a quantitative method. Based on the proposed research model, the quantitative model is the best suitable method to draw conclusions utilizing techniques that emphasize the validity and the reliability.

\subsection{Theoretical Framework and Hypotheses}

The framework below shows the study hypotheses, which examines the interrelationships between examination variables. The framework hypothesizes that leadership style (LS), the organizational climate (OC), and work style (WS) influences job satisfaction (JS). The model depicted in Figure 1 suggests that job satisfaction (JS) is the endogenous variable, which is influenced by leadership style (LS) as an exogenous variable. Moreover, the effect of LS on JS is mediated by the organizational climate (OC) and work style (WS) or $\eta=f(\xi 1, \xi 2, \xi 3)$. Where $\eta$ is job satisfaction (JS), $\xi 1$ will be leadership style (LS), $\xi 2$ will be the organizational climate (OC), and $\xi 3$ will be the work style (WS). OC and WS are not only the endogenous variables but also the mediators for $\eta$. Therefore, job satisfaction is a dependent variable (DV) that is influenced by the independent variables' leadership style (LS) and the mediating variables' organizational climate (OC) and work style (WS). The equation is visualized in Figure 1. 


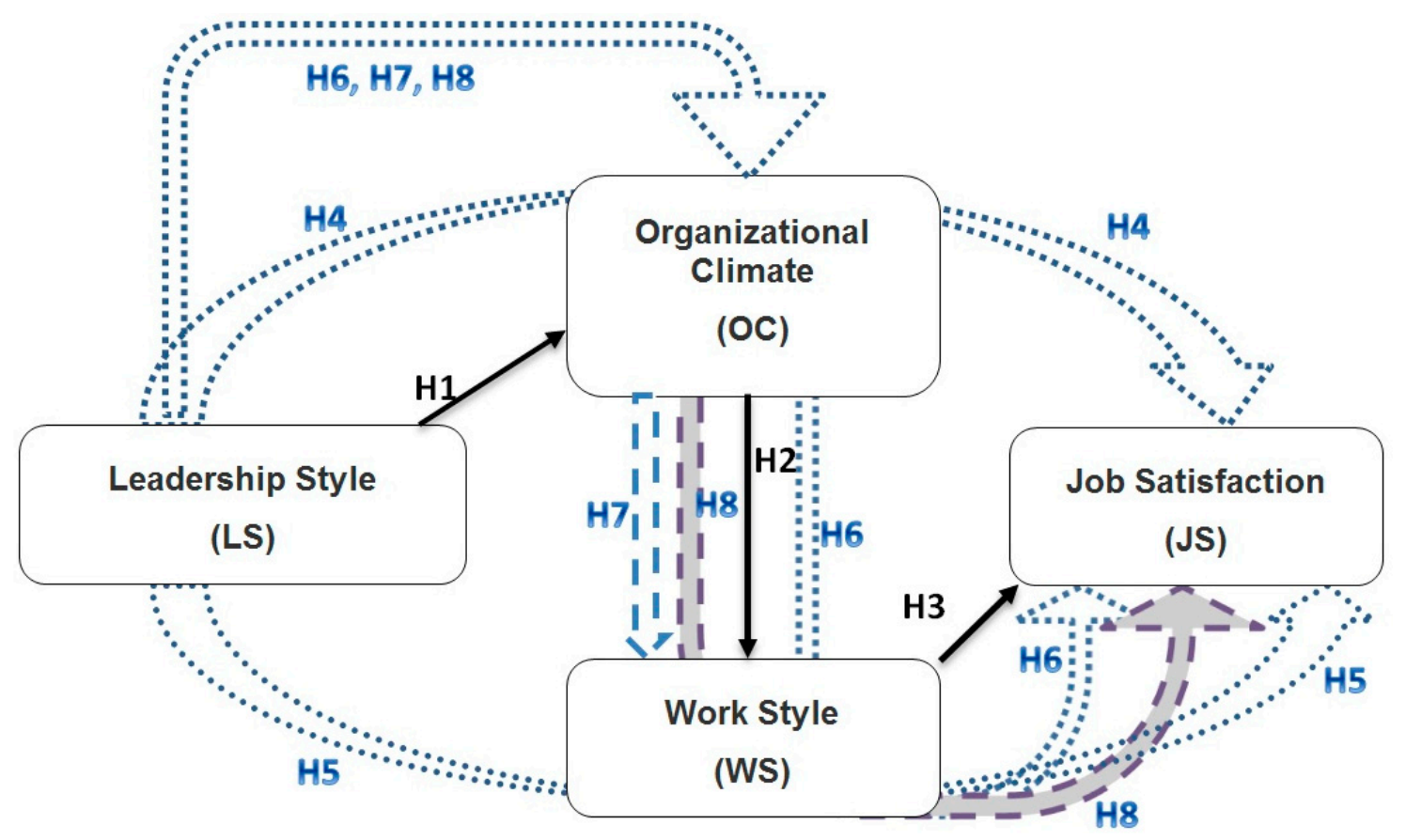

Figure 1. Research framework.

\section{Results and Findings}

A total of 200 questionnaires were distributed to employees of the register organization and 143 questionnaires were collected for this study. This paper studied a case and illustrated the demographics of respondents.

\subsection{Demographic Characteristics}

Eight major categories are computed to identify all the characteristics of the participants of this study. Demographics have shown that $23.1 \%$ of the respondents are male and $76.9 \%$ of the respondents are female. The profile of respondents exhibited the frequency and percentage of age dispersion, which was divided into five categories. The majority of the respondents are aged between 25-34 years old (44.8\%), which is followed by respondents aged 35-44 years old (37.1\%), 45 -to-55 years olds $(15.4 \%)$, and employees aged under 24 are $4(2.8 \%)$. In terms of the occupation, most of the respondents are lawyers $(58=40.6 \%)$. There are also other occupation types $(47=32.9 \%)$ and economists $(26=18.2 \%)$. These are related to the gender category. The highest percentage of respondents have a Bachelor's degree $(74.8 \%)$, which is followed by a Master's degree (24.5\%), and a Ph.D. and up is composed of only $0.7 \%$. Work duration in the register office is grouped into four categories. Most of the respondents have $0-5$ years of experience $(61=42.7 \%)$, which is followed by $6-10$ years $(55=38.5 \%), 11-15$ years $(21=14.7 \%)$ and then 16 years and more $(6=4.2 \%)$. The salary is divided into four categories: $46.9 \%$ of respondents have a salary with less than $\$ 300$ USD per month, which is followed by \$301-500 USD (39.9\%), \$501-500 USD (12.6\%), and respondents with a salary range of more than \$701 USD (0.7\%). From other descriptive statistics, most of the respondents are living in an apartment $(68=47.6 \%)$, which is followed by a private house $(33=23.1 \%)$, a rental $(30=21 \%)$, and respondents who live in a Mongolian traditional house $(12=8.4 \%)$. Final demographic information is working hours per day, which is partitioned into three measurements: 84 (58.7\%) of respondents work $9-12 \mathrm{~h}$, which is followed by $53(37.1 \%)$ respondents who work $8 \mathrm{~h}$ in a day, and then 6 people responded that they work $13 \mathrm{~h}$ and up. This occupied only $4.2 \%$ of all respondents for this research. 


\subsection{Test of Reliability and Validity}

Exploratory factor analysis (EFA) is an important tool for organizational researchers. It can be useful for refining measures, evaluating construct validity, and testing hypotheses. The general suggestion that, in order to get a good model, factorability of the Kaiser-Meyer-Olkin Measure of sampling adequacy $(\mathrm{KMO})$ must be greater than 0.6 , communality values must be greater than 0.5 , eigenvalues must be greater than 1 , and factor loadings should be at least 0.5 or higher [68].

From Table 1, all factor loadings are found to be higher than 0.5. KMO is 0.915 , which is higher than 0.6. Thus, the validity of the instrument for this study passed the Bartlett's Test of Sphericity. All factors have an Eigenvalue of 1 or greater. As shown in Table 1, reliability coefficient of each factor as well as the whole instrument is higher than the acceptable level of $(\alpha \geq 0.7)$. All factor loadings are above 0.7. In short, the results shown in Table 1 indicate that all factors are valid and reliable. Thus, we can further conduct additional statistical analysis, which is discussed in the next subsections.

Table 1. Factor Analysis, Instrument Validity, and Reliability.

\begin{tabular}{|c|c|c|c|c|c|c|c|}
\hline \multirow{2}{*}{ Variables } & \multirow{2}{*}{ Items } & \multirow{2}{*}{$\mathbf{M}$} & \multirow{2}{*}{ SD } & \multirow{2}{*}{$\begin{array}{c}\% \text { of } \\
\text { Variance }\end{array}$} & \multicolumn{2}{|c|}{ Loadings } & \multirow{2}{*}{$\begin{array}{l}\text { Cronbach's } \\
\text { Alpha }\end{array}$} \\
\hline & & & & & EFA & CFA & \\
\hline \multirow{4}{*}{ Leadership Style (LS) } & LS1 & 2.97 & 0.996 & \multirow{4}{*}{23.536} & 0.842 & 0.848 & \multirow{4}{*}{0.847} \\
\hline & LS2 & 3.07 & 1.066 & & 0.869 & 0.923 & \\
\hline & LS3 & 3.16 & 1.018 & & 0.855 & 0.913 & \\
\hline & LS4 & 2.83 & 0.957 & & 0.527 & 0.550 & \\
\hline \multirow{4}{*}{ Organizational Climate (OC) } & OC1 & 3.38 & 0.925 & \multirow{4}{*}{18.365} & 0.830 & 0.808 & \multirow{4}{*}{0.839} \\
\hline & OC2 & 3.10 & 0.894 & & 0.768 & 0.792 & \\
\hline & OC3 & 3.39 & 0.839 & & 0.755 & 0.799 & \\
\hline & OC4 & 3.24 & 0.864 & & 0.79 & 0.847 & \\
\hline \multirow{5}{*}{ Work style (WS) } & WS1 & 2.95 & 0.891 & \multirow{5}{*}{16.334} & 0.662 & 0.837 & \multirow{5}{*}{0.899} \\
\hline & WS2 & 2.94 & 0.882 & & 0.673 & 0.836 & \\
\hline & WS3 & 3.06 & 0.753 & & 0.679 & 0.872 & \\
\hline & WS4 & 2.89 & 1.101 & & 0.759 & 0.744 & \\
\hline & WS5 & 2.94 & 0.925 & & 0.641 & 0.769 & \\
\hline \multirow{2}{*}{ Job satisfaction (JS) } & JS3 & 3.55 & 1.787 & \multirow[t]{2}{*}{7.252} & 0.631 & 0.663 & \multirow[t]{2}{*}{0.718} \\
\hline & JS4 & 3.35 & 0.944 & & 0.894 & 0.882 & \\
\hline \multirow{2}{*}{ Instrument Total } & KMO & & & 0.915 & & & \multirow{2}{*}{0.921} \\
\hline & $p$-value & & & 0.000 & & & \\
\hline
\end{tabular}

Note: Item details are as follows: LS1: Stability and sustainability of my current job. LS2: The supervisor-subordinate relationship in registration (civil) office. LS3: The professional ability of my supervisor in registration (civil) office. LS4: My current working condition in the registration (civil) office. OC1: The relationship between co-workers in my organization (registration office). OC2: Having a professional status if I continue working in this organization. OC3: My success and outcome is from my current work. OC4: The way my co-workers get along with each other. WS1: The freedom to use my own judgment. WS2: A chance to do something for my coworkers. WS3: A chance to do different things from time to time. WS4: The chances for advancement at my current job. WS5: Encouragement and praise from my supervisor for my good job performance. JS3: I'm satisfied with the contents of my job in general. JS4: I'm satisfied about the workload in general.

\subsection{Confirmatory Factor Analysis (CFA)}

After conducting EFA, researchers use CFA. According to the CFA, variables WS2, WS5, and LS4 are removed to get a better fit for the model. Consequently, goodness of fit of each model is evaluated and compared with the suggested criteria by the ratio of chi-square to degrees of freedom $\left(\chi^{2} / \mathrm{df}\right)$, goodness-of-fit index (GFI), the adjusted goodness-of-fit index (AGFI), the root mean square error of approximation (RMSEA), and the comparative fit index (CFI). The measurement model of CFA in this model shows the fit index for the structural model, which indicated a good fit $\left(\chi^{2} / \mathrm{df}=1.342\right)$, RMSEA $=0.049, \mathrm{NFI}=0.895, \mathrm{CFI}=0.970, \mathrm{GFI}=0.903$ ). Based on these statistics, the CFA model is accepted and the model is fit. 


\subsection{Composite Reliability, Convergent, and Discriminant Validity}

Composite Reliability (CR), Convergent Validity, and Discriminant Validity are the extent to which indicators of a specific variable 'converge' or share a high proportion of variance in common. Convergent Validity includes two items: Composite Reliability (CR) and Average Variance Extracted (AVE). CR is a measure of reliability and internal consistency based on the square of the total of factor loadings for a construct [69]. AVE is a summary measure of convergence among a set of items representing a variable [70]. It is the average percent of variation explained among the items [69]. Anderson and Gerbing [69] suggest that the CR should be greater than 0.7 and Fornell and Larcker [70] suggest AVE to be at least 0.5 . Table 2 summarizes the results of validity and reliability. The results provide the evidence supporting the reliability and validity of the indicators of the research model [71].

Table 2. Test of composite reliability, convergent validity, and discriminant validity.

\begin{tabular}{ccccccccc}
\hline & CR & AVE & MSV & Max r & JS & WS & LS & OC \\
\hline JS & 0.753 & 0.609 & 0.417 & 0.646 & $\mathbf{0 . 7 8 0}$ & & & \\
WS & 0.907 & 0.661 & 0.648 & 0.805 & 0.646 & $\mathbf{0 . 8 1 3}$ & & \\
LS & 0.890 & 0.677 & 0.437 & 0.661 & 0.372 & 0.612 & $\mathbf{0 . 8 2 3}$ & \\
OC & 0.885 & 0.659 & 0.648 & 0.805 & 0.576 & 0.805 & 0.661 & $\mathbf{0 . 8 1 2}$ \\
\hline \multicolumn{7}{c}{ Note: CR $>0.7$, AVE $>0.5$, MSV $<$ AVE, $\sqrt{ }$ AVE $>$ Max r, $\sqrt{ }$ AVE is bold face diagonal. }
\end{tabular}

\subsection{Test of Hypotheses and Mediations}

This study employs Structural Equation Modeling in order to test our proposed model and all the formulated hypotheses, which was discussed in Section 3. The results of the model fit for the structural model include the following values: $\chi^{2} / \mathrm{df}=1.113(p>0.05), \mathrm{RMSEA}=0.028, \mathrm{NFI}=0.919, \mathrm{TLI}=0.989$, $\mathrm{CFI}=0.991$, and GFI $=0.923$. Table 3 recapitulates the results of hypotheses testing. Based on the results, three hypotheses are accepted $(\mathrm{H} 1, \mathrm{H} 2, \mathrm{H} 3)$.

Table 3. Results of the hypotheses (standardized regression weights).

\begin{tabular}{ccccc}
\hline Hypothesis & Paths & Estimate & Statement of Hypothesis & Results \\
\hline H1 & LS $\rightarrow$ OC & $0.622^{* * *}$ & LS has a positive association with OC & Supported \\
H2 & OC $\rightarrow$ WS & $0.812^{* * *}$ & OC has a positive association with WS & Supported \\
H3 & WS $\rightarrow$ JS & $0.665^{*}$ & WS has a positive association with JS & Supported \\
\hline \multicolumn{5}{c}{${ }^{*} p<0.055^{* * *} p<0.001}$.
\end{tabular}

Table 4 exhibits the result of the mediation hypotheses for the research model of this study. The results of mediation analysis, using 5000 resampling bootstrapping, support all mediation hypotheses (H4 H8) [72,73]. The following sections present meticulous discussion of the results shown in Tables 3 and 4.

Table 4. Results of the mediation hypotheses (standardized regression weights).

\begin{tabular}{|c|c|c|c|c|c|}
\hline & Path & Indirect (ab) & Direct $\left(c^{\prime}\right)$ & Total (c) & Mediation \\
\hline $\mathrm{H} 4$ & $\mathrm{LS} \rightarrow \mathrm{OC} \rightarrow \mathrm{JS}$ & $0.363^{* * *}$ & 0.016 (NS) & $0.379 * *$ & Supported \\
\hline H5 & $\mathrm{LS} \rightarrow \mathrm{WS} \rightarrow \mathrm{JS}$ & $0.414^{* * *}$ & 0.035 (NS) & $0.449 * *$ & Supported \\
\hline H6 & LS $\rightarrow$ (OC \& WS) $\rightarrow$ JS (Double Mediation) & $0.378^{* * *}$ & 0.012 (NS) & $0.390 *$ & Supported \\
\hline $\mathrm{H7}$ & $\mathrm{LS} \rightarrow \mathrm{OC} \rightarrow \mathrm{WS}$ & $0.475^{* * *}$ & 0.130 (NS) & $0.605^{* *}$ & Supported \\
\hline H8 & $\mathrm{OC} \rightarrow \mathrm{WS} \rightarrow \mathrm{JS}$ & $0.441 *$ & 0.128 (NS) & $0.569 * *$ & Supported \\
\hline
\end{tabular}




\section{Discussion and Managerial Implications}

\subsection{The Influence of Leadership Style (LS) on the Organizational Climate (OC)}

Our findings exhibited in Table 3 accept $\mathrm{H} 1$ and conclude that LS has a positive association with OC. This important finding exhibits the positive and strong influence of LS on OC for register office employees in Mongolia. According to Jung et al. [25], a good organizational climate means a comfortable workplace. The leaders and managers of the organization create a content office. Consequently, the positive relationship between OC and LS is of utmost importance. Therefore, an effective leadership style can improve the organizational climate and, therefore, develop the organization's morale and upturn employee effectiveness.

This finding is also consistent with prior scholars' findings [27] emphasizing more support for the model with the Mongolian public register sector. The result shows strong $(\beta=0.622)$ and significant $(p<0.001)$ influence of leadership style on the organizational climate of the register sector. Therefore, $\mathrm{H} 1$ is accepted.

5.2. The Influence of Leadership Style (LS) on Job Satisfaction (JS) (Single Mediation of Organizational Climate and Mediation of Work Style)

H2 states that LS influences JS and hypothesizes that LS has a positive association with JS. The results of SEM analyses, however, indicate that, for the given model, the leadership style does not influence job satisfaction directly. $\mathrm{H} 2$ is, therefore, rejected. This result may not be consistent with some of the previous findings $[49,52,53]$. However, the previous studies did not take into consideration the mediation influences of the organizational climate (OC) and work style (WS). The proposed model of this study leads to a new discovery regarding the mediation of OC and WS (Table 4) as single separate mediators. Therefore, $\mathrm{H} 4$ and $\mathrm{H} 5$ are supported.

\subsection{The Influence of the Leadership Style on Job Satisfaction (Serial Mediations of Organizational Climate and} Work Style)

Hayes [74] illustrates serial multiple mediations with data from research conducted by Tal-Or et al. [75]. We showed that OC and WS as separate single mediators fully mediate the relationship between LS and JS. Furthermore, based on Hayes [74], we tested the serial multiple mediations of OC and WS. The result indicated full double mediation of OC and WS for the relationship between LS and JS (Table 4). Therefore, $\mathrm{H} 6$ is supported. This finding underscores the importance of OC and WS as the mediator between LS and JS.

\subsection{The Influence of Leadership Style on Work Style and the Mediation of the Organizational Climate}

H3 proposes that LS has a significant influence on OC. The structural model of this study rejects this hypothesis. Therefore, $\mathrm{H} 3$ is rejected. Furthermore, $\mathrm{H} 10$ states that $\mathrm{OC}$ is the mediator between LS and WS. The result of SEM analyses using the bootstrapping technique indicates that, for the given model, even though LS does not have a direct influence on WS, OC fully mediates the relationship between LS and WS. Therefore, H7 accepted.

\subsection{The Influence of Organizational Climate (OC) on Work Style (WS)}

H4 hypothesizes that OC has a positive association with WS. Niculiţă [33] indicates that "organizational climate factors such as positive motivation, positive interpersonal relationships, efficient management, and organizational support have proven to deliver positive influence on specific work style factors" (p. 1042). The results of current path analyses, which are shown in Table 3, indicate that OC significantly and positively influence WS ( $\beta=0.812$ and $p<0.001) . \mathrm{H} 2$ is, therefore, supported. 


\subsection{The influence of Organizational Climate (OC) on Job Satisfaction (JS) and the Mediation of Work Style (WS)}

$\mathrm{H} 5$ hypothesizes that OC has a positive association with JS. Several previous studies $[41,65,66]$ have obtained the positive and significant relationship between the organizational climate and job satisfaction. However, the results of the path analyses indicate (Table 3) that, with the presence of work style, there is no significant influence of OC on JS. H5 is, therefore, rejected.

The finding, however, leads to another more important discovery regarding the mediation effect of work style, which was proposed by the new model (Table 4). WS fully mediates the influence of OC on JS. Thus, H11 is accepted. A good organizational climate requires a fair and clear policy, clear information, and an effective leader. Although the finding is not consistent with previous studies regarding the direct effect of OC on JS, this study introduces the significant mediating role of WS.

\subsection{The Influence of Work Style (WS) on Job Satisfaction (JS)}

H6 states that WS has a positive association with JS. Many studies [31,43-48,76] have acquired the positive and significant relationship between work style and job satisfaction. The result of this study ( $\beta=0.665, p<0.001)$ is consistent with a previous study and, consequently, H3 is accepted.

\subsection{Discussion}

In recent years, numerous scholars have been studying the relationship between employees' job satisfaction (JS) and respective factors such as leadership style (LS), organizational climate (OC), and work style (WS). However, very few papers have considered the above issue in the public sector. In addition, previous studies only found a direct and positive effect on employees' job satisfaction (JS) but ignored the mediating effects. This is one of the most important issues for human resource management because this could help improve employees' job satisfaction if we know its relationship with LS, OC, and WS. Our goal is to identify the factors influencing employees' job satisfaction. Furthermore, this study proposes a new model not only to test the direct effects but also the mediating effects on employees' job satisfaction. Thus, this paper bridges the gap of the literature to study the issue using Mongolian register office employees.

Previous studies have shown the importance of LS on JS and employee turnover. The proposed model of this study illustrates the importance of OC and WS in the relationship between the LS and JS. Leadership is one of the main factors for success in any kind of group activities. The workers-leader relationship is a key factor that influences workers' satisfaction in the workplace. However, what about employees' perceptions about organizational features like decision-making and rule setting in the workplace? The organizational climate is specific for each group and one leadership style will not fit all climates. Leaders need to rely on a positive climate in their workplace to enhance employee motivation and satisfaction. The proposed model of this study gives strong evidence for the important role of the organizational climate in order to increase job satisfaction.

Likewise, the harmony and accord of individual's professional activities and moral qualities are essential to one's satisfaction in life and work. Working style is stable and trait-like attributes of an employee. An individual's work style is developed in childhood through experimentation and reinforcement and then crystallized in adulthood. Leaders should pay attention to an individual's work style to develop sustainable and higher job satisfaction. The direct effect of LS on JS was studied. However, the results of this study introduce the intermediary role of WS on JS. Thus, when LS is combined with OC, WS will result in sustainable and higher JS.

Providing the right leadership is the key element in employee job satisfaction. However, the leaders should also take into consideration the organizational climate as well as employees' work style. In organizations with skillful employees and a good leadership style, a proper organizational climate and consideration for employees' work style would further influence job satisfaction and can improve employee retention. 
Findings of this study contribute to research on job satisfaction by delineating several combinations of antecedents that influence employees' job satisfaction in order to register the organization of Mongolia. For employees, working in public sector organizations may require effort to improve his/her moral and attention for the advancement of high productivity. Nevertheless, working in a positive organizational climate and identifying with a suitable leadership style can improve job satisfaction in register offices. Thus, when officers of the register office create a positive organizational climate through positive interaction as well as an appropriate leadership style to match employees' work style, employees' job satisfaction will be high. Leadership style will help job satisfaction, but sustainability of job satisfaction relies on the organizational climate and the work style of employees. When leaders of an organization implement employee's work style into their leadership style, job satisfaction increases. The suitable organizational climate will also influence employees' work style. The combination of the organizational climate and work style implemented properly into the leadership style would improve the sustainability of the job satisfaction level.

\subsection{Managerial Implications}

The results of current research show that respective factors are important to study employees' job satisfaction. Managers can use the results to improve planning of the human resource strategy and implement their leadership style more effectively. The results also suggested that not only effective leadership style is required in this sector. The mediating role of the organizational climate and work style should not be ignored. Furthermore, by using the proposed research model, this research can be expanded to other public sector organizations employees' job satisfaction.

A good understanding of the mediating role of work style and organizational climate would improve the influence of leadership style on job satisfaction. Our research provides guidance for Mongolian public office managers who wonder what they should do to improve job satisfaction. The findings of this study will be utilized for the managerial practice and improvement of human resource policy.

\section{Conclusions}

This study bases itself on the traditional variables relating to job satisfaction with the new model to suggest mediating variables that can help sustain employees' satisfaction. Furthermore, Mongolia as one of the emerging economies seldom has been the topic of various studies. Findings of this study paves the road to research on job satisfaction by outlining traditional antecedents that influence employees' job satisfaction and integrating them into a new model. This is the first study to investigate the relationship between leadership style and job satisfaction with Mongolian public sector employees. The main emphasis of this paper is to show the importance of the mediators. The findings of this study reconfirm the previous studies' outcomes that are associated with the positive influence of leadership style on the organizational climate. Likewise, the positive and significant influence of organizational climate on work style is tested and confirmed. Furthermore, we established and reconfirmed the positive significant influence of work style on job satisfaction.

The first three hypotheses were to show and reconfirm the external validity of the study. The next five hypotheses introduced in this model bring new discoveries and reiterate the importance of work style and organizational climate as the mediating variables. The role of the mediating variables is to improve sustainability of the relationship between leadership style and job satisfaction. The organizational climate is a significant mediator that fully binds and helps sustain the relationship between leadership style and job satisfaction. The same is true for work style. The organizational climate and work style combination, as the mediators helping the sustainability of the relationship between leadership style and job satisfaction, is also tested and the results show strong significant full mediation. The organizational climate fully mediates the relationship between leadership style and work style. Therefore, leaders can create a more sustainable work style by improving the organization's climate. This study signposts the importance of work style in sustaining the relationship between 
the organizational climate and job satisfaction. The organizational climate can sustainably influence employees' job satisfaction if the work style of each individual employee is respected and taken into account.

This paper studies sustainability of leadership and satisfied employees for the organizational climate and work style. An extension of our paper could study sustainability of leadership and satisfied employees for other variables. Further research could also study sustainability for other issues. For example, extending Mou et al. [77] and others to study the sustainability for enterprise supply chains, extend $\mathrm{Li}$ et al. [78] and others to study the sustainability of portfolio selection, extend Tsendsuren et al. [79] and others to study the sustainability of life insurance, extend Wong, et al. [80] to study the sustainability of warrant markets, extend Liao and Wong [81], Liao et al. [82], Purevdulam et al. [83], Moslehpour et al. [71] to study the sustainability of e-shopping, extend Pham et al. [84] to study the sustainability of outsourcing business, and extend Moslehpour et al. [85,86] to study the sustainability of marketing. This study is limited to public employees of the Mongolian public sector in Ulaanbaatar. However, the capital of Ulaanbaatar has 9 districts and 152 primary units of registration office. Future studies need to study the private sector employees in Mongolia and look at the differences if there are any.

The Government of Mongolia, as one of the emerging economies of the world, strives to implement appropriate human resource strategy to satisfy and retain government employees. There is an inevitable need for the sustainability of leadership and satisfied employees. Mongolian government organizations can benefit from empirical studies to implement a good human resource strategy. This study provides an opportunity to establish the fundamental basis by providing the grounds for future studies in this area. In practice, leaders and supervisors should pay attention to which factors are the most important and influential in the current transitional situation of Mongolia. Especially, as discussed in this study, factors such as organizational climate and work style are essential for the sustainability of the path between leadership style and employee satisfaction. Therefore, they must focus on human research management in theory and practice.

Author Contributions: In this paper, M.M. initiated the ideas and formulated the problems. P.A. performed the experiments, conducted the analysis, and wrote the first draft. W.M. contributed some useful materials to our paper. W.-K.W. assisted M.M. and P.A. in the detailed planning, conceiving and designing the experiments, and writing the entire paper.

Funding: This research received no external funding.

Conflicts of Interest: The authors declare no conflict of interest.

\section{References}

1. Uslu, T. Innovation culture and strategic human resource management in public and private sector within the framework of employee ownership. Procedia-Soc. Behav. Sci. 2015, 195, 1463-1470. [CrossRef]

2. Buchanan, B. Government managers, business executives, and organizational commitment. Public Adm. Rev. 1974, 339-347. [CrossRef]

3. Lachman, R. Public and private sector differences: CEOs' perceptions of their role environments. Acad. Manag. J. 1985, 28, 671-680.

4. Marques, I.; Willis, S.C.; Schafheutle, E.I.; Hassell, K. Development of an instrument to measure organisational culture in community pharmacies in Great Britain. J. Health Organ. Manag. 2018, 32, 176-189. [CrossRef] [PubMed]

5. Chang, S.; Jia, L.; Takeuchi, R.; Cai, Y. Do high-commitment work systems affect creativity? A multilevel combinational approach to employee creativity. J. Appl. Psychol. 2014, 99, 665. [CrossRef]

6. Cumbey, D.A.; Alexander, J.W. The relationship of job satisfaction with organizational variables in public health nursing. J. Nurs. Adm. 1998, 28, 39-46. [CrossRef]

7. Gumusluoglu, L.; Ilsev, A. Transformational leadership, creativity, and organizational innovation. J. Bus. Res. 2009, 62, 461-473. [CrossRef] 
8. Tovey, E.J.; Adams, A.E. The changing nature of nurses' job satisfaction: An exploration of sources of satisfaction in the 1990s. J. Adv. Nurs. 1999, 30, 150-158. [CrossRef]

9. Singh, H.; Saufi, R.A.; Tasnim, R.; Hussin, M. The relationship between employee job satisfaction, perceived customer satisfaction, service quality, and profitability in luxury hotels in Kuala Lumpur. Prabandhan Indian J. Manag. 2017, 10, 26-39. [CrossRef]

10. Dansereau, F., Jr.; Graen, G.; Haga, W.J. A vertical dyad linkage approach to leadership within formal organizations: A longitudinal investigation of the role making process. Organ. Behav. Hum. Perform. 1975, 13, 46-78. [CrossRef]

11. Wilkinson, A.D.; Wagner, R.M. Supervisory Leadership Styles and State Vocational Rehabilitation Counselor Job Satisfaction and Productivity. Rehabil. Couns. Bull. 1993, 37, 15-24.

12. Drucker, P. Geleceğin Toplumunda Yönetim, (Çev. Zaman, M.); Hayat Yayıncılık: Stanbul, Turkey, 2003.

13. Edgar, F.; Geare, A. HRM practice and employee attitudes: Different measures-different results. Pers. Rev. 2005, 34, 534-549. [CrossRef]

14. Alola, U.; Avci, T.; Ozturen, A. Organization Sustainability through Human Resource Capital: The Impacts of Supervisor Incivility and Self-Efficacy. Sustainability 2018, 10, 2610. [CrossRef]

15. Sofarelli, D.; Brown, D. The need for nursing leadership in uncertain times. J. Nurs. Manag. 1998, 6, $201-207$. [CrossRef] [PubMed]

16. Thyer, G.L. Dare to be different: Transformational leadership may hold the key to reducing the nursing shortage. J. Nurs. Manag. 2003, 11, 73-79. [CrossRef]

17. Renko, M.; El Tarabishy, A.; Carsrud, A.L.; Brännback, M. Understanding and measuring entrepreneurial leadership style. J. Small Bus. Manag. 2015, 53, 54-74. [CrossRef]

18. McGregor, D. The Human Side of Enterprise; McGraw-Hill Book Company: New York, NY, USA, 1960.

19. Forehand, G.A.; Von Haller, G. Environmental variation in studies of organizational behavior. Psychol. Bull. 1964, 62, 361. [CrossRef]

20. Burke, W.W.; Litwin, G.H. A causal model of organizational performance and change. J. Manag. 1992, 18, 523-545. [CrossRef]

21. Gorsira, M.; Steg, L.; Denkers, A.; Huisman, W. Corruption in organizations: Ethical climate and individual motives. Adm. Sci. 2018, 8, 4. [CrossRef]

22. Griffin, M.L. Job satisfaction among detention officers: Assessing the relative contribution of organizational climate variables. J. Crim. Justice 2001, 29, 219-232. [CrossRef]

23. Chang, P.-C.; Wu, T.; Liu, C.-L. Do High-Performance Work Systems Really Satisfy Employees? Evidence from China. Sustainability 2018, 10, 3360. [CrossRef]

24. Sánchez Sellero, M.C.; Sánchez Sellero, P. Factores Determinantes de la Satisfacción Laboral en España antes y Durante la Crisis de 2008. OmniaScience 2016, 12, 1192-1220.

25. Jung, D.I.; Chow, C.; Wu, A. The role of transformational leadership in enhancing organizational innovation: Hypotheses and some preliminary findings. Leadersh. Q. 2003, 14, 525-544. [CrossRef]

26. Jung, H.-J.; Ali, M. Corporate Social Responsibility, Organizational Justice and Positive Employee Attitudes: In the Context of Korean Employment Relations. Sustainability 2017, 9, 1992. [CrossRef]

27. Ekvall, G.; Ryhammar, L. Leadership style, social climate and organizational outcomes: A study of a Swedish University College. Creat. Innov. Manag. 1998, 7, 126-130. [CrossRef]

28. Kao, R.-H. The relationship between work characteristics and change-oriented organizational citizenship behavior: A multi-level study on transformational leadership and organizational climate in immigration workers. Pers. Rev. 2017, 46, 1890-1914. [CrossRef]

29. Maamari, B.E.; Majdalani, J.F. Emotional intelligence, leadership style and organizational climate. Int. J. Organ. Anal. 2017, 25, 327-345. [CrossRef]

30. Mihuț, I. Self-Management and Creativity; Dacia: Cluj-Napoca, Romania, 1989.

31. Dawis, R.V.; Lofquist, L.H. A Psychological Theory of Work Adjustment: An Individual Differences Model and Its Application; University of Minnesota: Minneapolis, MN, USA, 1984.

32. Dawis, R.V. The Minnesota Theory of Work Adjustment. In Career Development and Counseling: Putting Theory and Research to Work; Brown, S.D., Lent, R.W., Eds.; John Wiley \& Sons Inc.: Hoboken, NJ, USA, 2005.

33. Niculiţă, Z. The relationship between work style and organizational climate for Romanian employees. Procedia Econ. Financ. 2015, 32, 1042-1049. [CrossRef] 
34. Locke, E.A.; Dunnette, M.D. Handbook of industrial and organizational psychology. Nat. Causes Job Satisf. 1976, 1297-1349.

35. Spector, P.E. Measurement of human service staff satisfaction: Development of the Job Satisfaction Survey. Am. J. Community Psychol. 1985, 13, 693-713. [CrossRef]

36. Brief, A.P. Attitudes in and around Organizations; Sage: Newcastle upon Tyne, UK, 1998; Volume 9.

37. Mathieu, J.E.; Zajac, D.M. A review and meta-analysis of the antecedents, correlates, and consequences of organizational commitment. Psychol. Bull. 1990, 108, 171. [CrossRef]

38. Hirschfeld, R.R.; Feild, H.S.; Bedeian, A.G. Work Alienation as an Individual-Difference Construct for Predicting Workplace Adjustment: A Test in Two Samples 1. J. Appl. Soc. Psychol. 2000, 30, 1880-1902. [CrossRef]

39. Altuntas, S.; Baykal, U. Relationship between nurses' organizational trust levels and their organizational citizenship behaviors. J. Nurs. Sch. 2010, 42, 186-194. [CrossRef] [PubMed]

40. Durst, S.L.; DeSantis, V.S. The determinants of job satisfaction among federal, state, and local government employees. State Local Gov. Rev. 1997, 29, 7-16. [CrossRef]

41. Hashemi, J.; Sadeqi, D. The relationship between job satisfaction and organizational climate: A case study of government departments in Divandarreh. World Sci. News 2016, 45, 373-383.

42. Arbuckle, M.R.; DeGolia, S.G.; Esposito, K.; Miller, D.A.; Weinberg, M.; Brenner, A.M. Associate residency training directors in psychiatry: Demographics, professional activities, and job satisfaction. Acad. Psychiatry 2012, 36, 391-394. [CrossRef]

43. Chang, W.Y.; Ma, J.C.; Chiu, H.T.; Lin, K.C.; Lee, P.H. Job satisfaction and perceptions of quality of patient care, collaboration and teamwork in acute care hospitals. J. Adv. Nurs. 2009, 65, 1946-1955. [CrossRef]

44. Chuang, E.; Dill, J.; Morgan, J.C.; Konrad, T.R. A configurational approach to the relationship between high-performance work practices and frontline health care worker outcomes. Health Serv. Res. 2012, 47, 1460-1481. [CrossRef]

45. Harley, B.; Allen, B.C.; Sargent, L.D. High performance work systems and employee experience of work in the service sector: The case of aged care. Br. J. Ind. Relat. 2007, 45, 607-633. [CrossRef]

46. Harmon, J.; Scotti, D.J.; Behson, S.; Farias, G. Effects of high-involvement work systems on employee satisfaction and service costs in veterans healthcare. J. Healthc. Manag. 2003, 48, 393. [CrossRef]

47. Young, S.; Bartram, T.; Stanton, P.; Leggat, S.G. High performance work systems and employee well-being: A two stage study of a rural Australian hospital. J. Health Organ. Manag. 2010, 24, 182-199. [CrossRef] [PubMed]

48. Fan, D.; Cui, L.; Zhang, M.M.; Zhu, C.J.; Härtel, C.E.; Nyland, C. Influence of high performance work systems on employee subjective well-being and job burnout: Empirical evidence from the Chinese healthcare sector. Int. J. Hum. Resour. Manag. 2014, 25, 931-950. [CrossRef]

49. Lok, P.; Crawford, J. The effect of organisational culture and leadership style on job satisfaction and organisational commitment: A cross-national comparison. J. Manag. Dev. 2004, 23, 321-338. [CrossRef]

50. McColl-Kennedy, J.R.; Anderson, R.D. Subordinate-manager gender combination and perceived leadership style influence on emotions, self-esteem and organizational commitment. J. Bus. Res. 2005, 58, 115-125. [CrossRef]

51. Afshinpour, S. Leadership Styles and Employee Satisfaction: A Correlation Study. Int. Lett. Soc. Humanist. Sci. ILSHS 2014, 16, 156-169.

52. Alonderiene, R.; Majauskaite, M. Leadership style and job satisfaction in higher education institutions. Int. J. Educ. Manag. 2016, 30, 140-164. [CrossRef]

53. Babalola, S.S. The effect of leadership style, job satisfaction and employee-supervisor relationship on job performance and organizational commitment. J. Appl. Bus. Res. 2016, 32, 935. [CrossRef]

54. Brimhall, K.C.; Mor Barak, M.E.; Hurlburt, M.; McArdle, J.J.; Palinkas, L.; Henwood, B. Increasing workplace inclusion: The promise of leader-member exchange. Hum. Serv. Organ. Manag. Leadersh. Gov. 2017, 41, 222-239. [CrossRef]

55. Wu, X.; Yin, W.; Wu, C.; Luo, X. The Spillover Effects on Employees' Life of Construction Enterprises' Safety Climate. Sustainability 2017, 9, 2060. [CrossRef]

56. Priyankara, H.P.R.; Luo, F.; Saeed, A.; Nubuor, S.A.; Jayasuriya, M.P.F. How Does Leader's Support for Environment Promote Organizational Citizenship Behaviour for Environment? A Multi-Theory Perspective. Sustainability 2018, 10, 271. [CrossRef] 
57. Scherpereel, C.M.; Bowers, M.Y. Using critical problem based learning factors in an integrated undergraduate business curriculum: A business course success. In Proceedings of the Annual ABSEL Conference on Developments in Business Simulation and Experiential Learning, 2014. Available online: https://www. google.com.hk/url?sa=t\&rct=j\&q=\&esrc=s\&source=web\&cd=1\&cad=rja\&uact=8\&ved=2ahUKEwix0Z_ Z6pvfAhVWEnAKHZiLDwsQFjAAegQIChAC\&url=https\%3A\%2F\%2Fjournals.tdl.org\%2Fabsel\% 2Findex.php\%2Fabsel\%2Farticle\%2Fdownload\%2F493\%2F462\&usg=AOvVaw25wZ8bk2j9WgjwY11_iki(accessed on 12 December 2018).

58. Borges, N.J.; Savickas, S. Work style preferences among medical specialties. J. Vocat. Behav. 2014, 84, 303-306. [CrossRef]

59. Holloway, J.C. The guided tour a sociological approach. Ann. Tour. Res. 1981, 8, 377-402. [CrossRef]

60. Wang, K.-C.; Jao, P.-C.; Chan, H.-C.; Chung, C.-H. Group package tour leader's intrinsic risks. Ann. Tour. Res. 2010, 37, 154-179. [CrossRef]

61. Sarros, J.C.; Tanewski, G.A.; Winter, R.P.; Santora, J.C.; Densten, I.L. Work alienation and organizational leadership. Br. J. Manag. 2002, 13, 285-304. [CrossRef]

62. Chen, P.Y.; Spector, P.E. Negative affectivity as the underlying cause of correlations between stressors and strains. J. Appl. Psychol. 1991, 76, 398. [CrossRef] [PubMed]

63. Brockner, J. Self-Esteem at Work: Research, Theory, and Practice; Lexington Books/DC Heath and Com: Lexington, MA, USA, 1988.

64. De Cremer, D. Why inconsistent leadership is regarded as procedurally unfair: The importance of social self-esteem concerns. Eur. J. Soc. Psychol. 2003, 33, 535-550. [CrossRef]

65. Tsai, C.-L. The organizational climate and employees' job satisfaction in the Terminal Operation Context of Kaohsiung Port. Asian J. Ship Log 2014, 30, 373-392. [CrossRef]

66. Ángel Calderón Molina, M.; Manuel Hurtado González, J.; Palacios Florencio, B.; Luis Galán González, J. Does the balanced scorecard adoption enhance the levels of organizational climate, employees' commitment, job satisfaction and job dedication? Manag. Decis. 2014, 52, 983-1010. [CrossRef]

67. Ahmad, K.Z.B.; Jasimuddin, S.M.; Kee, W.L. Organizational climate and job satisfaction: Do employees' personalities matter? Manag. Decis. 2018, 56, 421-440. [CrossRef]

68. Tabachnick, B.G.; Fidell, L.S. Principal components and factor analysis. Using Multivar. Stat. 2001, 4, $582-633$.

69. Anderson, J.C.; Gerbing, D.W. Structural equation modeling in practice: A review and recommended two-step approach. Psychol. Bull. 1988, 103, 411. [CrossRef]

70. Fornell, C.; Larcker, D.F. Structural equation models with unobservable variables and measurement error: Algebra and statistics. J. Mark. Res. 1981, 382-388. [CrossRef]

71. Moslehpour, M.; Pham, V.K.; Wong, W.-K.; Bilgiçli, İ. e-Purchase Intention of Taiwanese Consumers: Sustainable Mediation of Perceived Usefulness and Perceived Ease of Use. Sustainability 2018, 10, 234. [CrossRef]

72. Bollen, K.A.; Stine, R. Direct and indirect effects: Classical and bootstrap estimates of variability. Sociol. Methodol. 1990, 115-140. [CrossRef]

73. Shrout, P.E.; Bolger, N. Mediation in experimental and nonexperimental studies: New procedures and recommendations. Psychol. Methods 2002, 7, 422. [CrossRef] [PubMed]

74. Hayes, A.F. Introduction to Mediation, Moderation, and Conditional Process Analysis: A Regression-Based Approach; The Guilford Press: New York, NY, USA, 2013.

75. Tal-Or, N.; Cohen, J.; Tsfati, Y.; Gunther, A.C. Testing causal direction in the influence of presumed media influence. Commun. Res. 2010, 37, 801-824. [CrossRef]

76. Weinberg, D.B.; Avgar, A.C.; Sugrue, N.M.; Cooney-Miner, D. The importance of a high-performance work environment in hospitals. Health Serv. Res. 2013, 48, 319-332. [CrossRef] [PubMed]

77. Mou, W.; Wong, W.-K.; McAleer, M. Financial credit risk evaluation based on core enterprise supply chains. Sustainability 2018, 10, 3699. [CrossRef]

78. Li, Z.; Li, X.; Hui, Y.; Wong, W.-K. Maslow Portfolio Selection for Individuals with Low Financial Sustainability. Sustainability 2018, 10, 1128. [CrossRef]

79. Tsendsuren, S.; Li, C.-S.; Peng, S.-C.; Wong, W.-K. The Effects of Health Status on Life Insurance Holdings in 16 European Countries. Sustainability 2018, 10, 3454. [CrossRef]

80. Wong, W.-K.; Lean, H.; McAleer, M.; Tsai, F.-T. Why Are Warrant Markets Sustained in Taiwan but Not in China? Sustainability 2018, 10, 3748. [CrossRef] 
81. Liao, Z.; Wong, W.-K. The determinants of customer interactions with internet-enabled e-banking services. J. Oper. Res. Soc. 2008, 59, 1201-1210. [CrossRef]

82. Liao, Z.; Shi, X.; Wong, W.-K. Consumer perceptions of the smartcard in retailing: An empirical study. J. Int. Consum. Mark. 2012, 24, 252-262. [CrossRef]

83. Altantsetseg, P.; Chen, K.C.; Chang, M.L. Male and female leaders' entrepreneurial leadership: A comparative study of Mongolia, Taiwan and Thailand on leader-member exchange. J. Adm. Bus. Stud. 2017, 3, 144-152.

84. Pham, V.; Wong, W.; Moslehpour, M.; Musyoki, D. Simultaneous Adaptation of AHP and Fuzzy AHP to Evaluate Outsourcing Service in East and Southeast Asia. J. Test. Eval. 2018, 48. [CrossRef]

85. Moslehpour, M.; Wong, W.-K.; Pham, K.V.; Aulia, C.K. Repurchase intention of Korean beauty products among Taiwanese consumers. Asia Pac. J. Mark. Logist. 2017, 29, 569-588. [CrossRef]

86. Moslehpour, M.; Wong, W.-K.; Lin, Y.H.; Nguyen, T.L.H. Top purchase intention priorities of Vietnamese low cost carrier passengers: Expectations and satisfaction. Eurasian Bus. Rev. 2018, 8, 371-389. [CrossRef]

C 2018 by the authors. Licensee MDPI, Basel, Switzerland. This article is an open access article distributed under the terms and conditions of the Creative Commons Attribution (CC BY) license (http:// creativecommons.org/licenses/by/4.0/). 